\title{
Race for Foreign Direct Investment: Turkey vs. Poland
}

\author{
Yi Jiang \\ Associate Professor, Department of Management \\ California State University, East Bay, Hayward, USA \\ Wei Shen \\ Associate Professor, International Studies Department \\ École Supérieure des Sciences Commerciales d'Angers, Angers, France
}

\section{Doi:10.5901/ajis.2013.v2n11p129}

\begin{abstract}
Comparing foreign direct investment (FDI) in Turkey and Poland, this paper explores location choices and organizational forms of FDI in emerging economies. We adopt transaction cost economics and institution-based view to investigate the relationships between location, entry mode, and ownership structure. We validate the significance of EU accession as a determinant of FDI and show that a politically stable environment attracts FDI, but the sheer size of a market does not attract FDI. Our findings suggest that different organizational forms of FDI are favored in different institutional environments.
\end{abstract}

\section{Introduction}

Foreign direct investment (FDI) has substantial impact on the host country. FDI contributes to local employment, productivity, and knowledge transfer, especially in emerging economies. During the economic liberalization process, foreign investment has played an important role in transforming ownership structure and strengthening corporate governance. In addition to providing management and technological expertise, multinational enterprise (MNE) also brings credibility to the host country. This credibility may in turn attract further FDI. International market selection and choice of entry mode are crucial decisions that foreign investors need to make. To attract FDI, countries must acquire and build new competitiveness and leverage their locational advantage.

By 1990, global inflows of FDI have reached $\$ 234$ billion (UNCTAD, 1994) and by 2009, global inflows of FDI reached $\$ 1,114$ billion (UNCTAD, 2010). The recent acceleration of FDI is fueled by policy liberalization of host countries, growth in mergers and acquisitions, and the expanding investment opportunities in newly privatized sectors. Privatization has been defined widely as the process of transferring ownership from the state to the private sector, and has been facilitated by the trend of broad market-oriented reforms in emerging economies around the world in the past few decades (Megginson \& Netter, 2001, Ramamurti, 2000). In Western Europe, privatization started in the 1980s due to increasing globalization and economic conditions (Clifton, Comín, \& Fuentes, 2003, Vickers \& Wright, 1989). Mass privatization programs started in Central and Eastern Europe (CEE) and Asia in the 1990s (Boycko, Shleifer, \& Vishny, 1994). While the emerging economies race to attract foreign direct investment, there is an obvious link between privatization and the inflow of foreign investment (Welfens, 1992).

The reason to study FDI in Turkey and Poland is twofold. First, Turkey's European Union (EU) membership depends on its adaptation to the EU standards, including creating supportive environment for FDI and facilitating privatization process. As an EU candidate country, Turkey may learn from a newly minted EU member regarding these issues. Second, both Poland and Turkey have abundant supplies of well-qualified labor that costs much less than Western countries. Out of the countries in Central and Eastern Europe (CEE) that have been granted official membership of the EU, Poland has the largest domestic market making it more comparable to Turkey regarding market size.

Turkey is situated in a politically unstable part of the world (Coskun, 2001). Geographically, Turkey is between Europe and Asia and has good access to Western Europe and the Middle East. As a member of the Black Sea Economic Co-operation Organization, Turkey supports regional cooperation with member countries including Russia. A free trade area was established between Turkey and the European Union through EU-Turkey Customs Union in 1996. Turkey was officially recognized as the candidate country for EU membership in 1999. Since 1986, Turkey has embarked on privatization programs that resulted in companies jointly owned by private sectors and the government (Keller, Dogan, \& 
Eroglu, 1994). In 2005, Turkey concluded the biggest privatization in the history, when Saudi Oger Ltd acquired a 55\% stake in former fixed phone line monopoly Turk Telekom for $\$ 6.55$ billion (Demirsar, 2006).

Having the largest domestic market in CEE, Poland has attracted significant FDI. After the fall of the Communist regimes, Poland has passed series of foreign investment laws (Bieszki \& Rath, 1989) and seen a major change of ownership structure towards the private sector in the 1990s (Wojnicka, 2001). Leszek Balcerowicz, the finance minister of Poland's first post communist government, started the Balcerowicz plan with a series of market reforms (Bockman \& Eyal, 2002). These reforms brought the institutional framework closer to that of Western countries.

Comparing FDI in Turkey and Poland, this study asks three research questions: (1) what are the location advantages of Poland versus Turkey? (2) What entry modes are favored by FDI in Turkey and Poland? (3) What ownership structures are favored by FDI in these two countries? The paper is constructed in three sections. The first section reviews literature and develops hypotheses. The second section empirically tests the hypotheses. The third section discusses findings and future research directions.

\section{Literature Review and Research Hypotheses}

Studies of the location choice of FDI have focused on motivations including cost reduction (Buckley \& Casson, 1998), transaction cost minimization (Buckley \& Casson, 1976, Hennart, 1982, Teece, 1986), market size (Buckley \& Mathew, 1980), and competence enhancement (Dunning, 1997, Kogut \& Zander, 2003). Dunning's (1980) OLI paradigm recognizes that foreign investors need to have ownership $(\mathrm{O})$ and internalization $(\mathrm{I})$ advantages and the host country needs to present location (L) advantages. Attraction of FDI lies in both factor endowments (Porter, 1990) and institutional contexts (Uhlenbruck \& De Castro, 2000, Wan \& Hoskisson, 2003) in the host country. The important factor endowments that attract FDI include natural resources, developed infrastructure, market size, economic growth potential, and labor supply. Studies have found that market size is positively related to FDI inflows in the host country (Bevan \& Estrin, 2004, Chidlow, Salciuviene, \& Young, 2009, Erdal \& Tatoglu, 2002).

Determinants of FDI locations change over time (Dunning, 1997). The changing aspects of locations are manifested particularly in the institutional context in emerging economies, where the transitional political, social, economic and legal systems often affect foreign investors' perceived market potential and investment risk (Agarwal \& Ramaswami, 1992, Ahmed, Mohamad, Tan, \& Johnson, 2002, Brouthers, Brouthers, \& Werner, 2002, Henisz, 2000). Institutional underdevelopment is a hallmark of emerging economies (Meyer \& Peng, 2005, Wright, Filatotchev, Hoskisson, \& Peng, 2005). The level of political stability varies considerably among emerging economies over time (De Castro \& Uhlenbruck, 1997).

Insights from transaction cost economics (TCE) suggest that more uncertainties lead to more transaction costs (Williamson, 1985). FDI may favor locations where they are less exposed to uncertainties and "hold up" problems (Williamson, 1985). Research integrating TCE and institution-based view (Martinez \& Dacin, 1999) recognizes uncertainty in the institutional environment as constraints on firm choices (Argyres \& Liebeskind, 1999). Some scholars argue that institution-based view is an insightful perspective when explaining firm behavior in emerging economies (Meyer, Estrin, Bhaumik, \& Peng, 2009, Peng, Wang, \& Jiang, 2008, Shenkar \& Von Glinow, 1994). As "rules of the game," institutions promote economic exchange and coordination by creating order and reducing uncertainty (North, 1990, Williamson, 1985). If the host country has more checks and balances and more political stability, opportunistic behavior from the local government is much less likely (Hoskisson, Eden, Lau, \& Wright, 2000). Factors such as the randomness of the market or the unpredictable discretion of the policy increases uncertainty in transactions (Choi, Lee, \& Kim, 1999). In an institutional environment where credible commitments by the government can be secured, foreign investors realize that the risk of having to adjust to the ever-changing regulatory structure is low (Henisz \& Zelner, 2001), thus are more likely to enter.

Hypothesis 1. A larger market is more likely to attract FDI.

Hypothesis 2. A market with more political stability is more likely to attract FDI.

\subsection{European Union}

Regional integrations contribute greatly to FDI. Membership in multilateral organizations like the European Union (EU) is a significant attraction to FDI (Baldwin, Francoise, \& Portes, 1997). EU countries are the major foreign investors in Poland and Turkey (Erdal \& Tatoglu, 2002, Wojnicka, 2001). European single market has had tremendous impact on FDI in private participation projects (Clifton, Comín, \& Fuentes, 2003). EU accession is attractive to foreign investors for two reasons. First, since EU accession is conditioned on liberalization to foreign capital, governments of EU candidate 
countries need to demonstrate their willingness to offer national assets to foreign investors (Bandelj, 2009). Second, the psychic distance between developed economies and emerging economies are greatly reduced by the convergence of markets (Myer, 2001) since it is widely believed that EU accession would enhance the institutional framework.

The relationship between Turkey and the EU has vacillated between support for and doubt over future membership. Concerns regarding political reform, competition law enforcement, intellectual property right protection, and justice system compatibility have continued to inhibit Turkey's accession to the EU. EU membership is vital if Turkey is to successfully compete for foreign investment.

Poland's accession to the EU in 2004 attracted FDI due to Poland's continued political commitment to economic liberalization and favorable policies toward foreign investment. Even before 2004 there may have been increased FDI in Poland in anticipation of the benefits of integration. With EU membership, Poland shows more attractiveness to FDI with more committed market reforms and shorter psychic distance from Western countries.

Hypothesis 3. Poland is more likely to attract FDI than Turkey.

Hypothesis 4. After EU accession, Poland's ability to attract FDI is stronger than Turkey's.

\subsection{Entry Mode and Ownership Structure}

Different forms of cross-border FDI may require particular locations. The location of FDI also affects the MNE organizational forms (Dunning, 1993, Dunning, 2009). Understanding of locational attractiveness to FDI is insufficient without recognizing the relationship between MNE's location choice and organizational forms.

Two decisions MNE needs to make regarding its organizational forms are entry mode and ownership structure (Dikova \& Van Witteloostuijn, 2007). Studies on entry mode choice recognize acquisition and greenfield as major modes to invest abroad and have applied transaction cost economics on entry modes broadly (Anderson \& Gatingnon, 1986, Hennart \& Park, 1993).

In transaction cost literature with respect to foreign market entry, information asymmetry has been recognized as a major source of high transaction costs and poses caution for the choice of entry modes (Buckley \& Casson, 1976, Meyer \& Peng, 2005). Institution-based view further recognizes that information asymmetry is greater in a less developed institutional environment due to inefficiencies in the markets and leads to greater transaction costs (Dikova \& Van Witteloostuijn, 2007, Estrin, Hughes, \& Todds, 1997, Meyer, 2001).

MNEs entering emerging economies face high information asymmetry (Hoskisson, Eden, Lau, \& Wright, 2000). Entering into a less developed institutional environment through an acquisition deal compensates foreign investors' lack of information in a target country in a few ways. Compared with greenfield entry mode, acquiring assets from a local entity provides opportunities for foreign investors to obtain a team of managers who are familiar with the local market (Dikova \& van Witteloostuijin, 2004) and gain product-specific knowledge (Hennart \& Park, 1993). An acquisition deal can also help foreign investors to get access to a larger pool of suppliers and customers in the existing business networks, which would have cost a lot more if they try to set up the network from scratch in a greenfield investment (Conner \& Prahalad, 1996, Peng \& Jiang, 2005). Facilitating rapid entry and access to local resources, acquisition investments in less developed institutional environments are more likely to gain first mover advantages (Meyer \& Estrin, 2001) and market specific experience (Ekeledo \& Sivakumar, 2004).

The level of institutional development of the host country plays an important role in the choice of entry mode. Organizations select coordination mechanisms that fit the host country (Meyer, 2001). Greenfield investment has the benefit of choosing the site that meets its needs best and preserving corporate culture abroad (Harzing, 2002). In a more developed institutional environment, the law-enforcement mechanisms may provide complementary resources for FDI to establish such a new facility. Greenfield investment also facilitates efficient transfer of assets from the home market (Hennart \& Park, 1993), nevertheless, it may require the host market regulations to assist such transfer.

Both Turkey and Poland are emerging economies that still experience a process of change towards more marketoriented economy. Given the EU accession status, we consider that Turkey has a less developed institutional environment than Poland. Since we argue that acquisition entry mode is more favorable in a less developed institutional environment, we propose:

Hypothesis 5. Acquisition projects are more likely to attract FDI in Turkey than in Poland and greenfield projects are more likely to attract FDI in Poland than in Turkey.

Foreign investors, in addition to choosing entry modes, need to select ownership structures. MNEs may choose to invest in the form of joint venture (JV) with local partners or wholly owned subsidiary (WOS). Studies have explored the relation between entry mode and ownership structure and presented mixed results (Demirbag, Tatoglu, \& Glaister, 2008). 
Gomes-Casseres (1989) finds a relationship between acquisitions and JVs, whereas Larimo (2003) argues that acquisition is related to WOS. Caves and Mehra (1986) report that acquisitions are less likely in establishing JVs.

Entry mode and ownership structure may be related in such a way that the decisions of both are affected by transaction costs. When transaction costs in a host country are high, joint venture with local partners may be favored to reduce uncertainty (Hennart, 1988). WOS shows high commitment and exposes the investors to substantial costs and risks in emerging economies (Agarwal \& Ramaswami, 1992, Filatotchev, Strange, Piesse, \& Yung-Chih, 2007) thus may be less favored in a less developed institutional environment. Studies show that FDI with higher commitments are only likely to be established in markets that progressed further in institutional reform while an ownership structure with lower resource commitments may provide firms with flexibility to react to volatile market conditions (Bell, 1996, Kim \& Huang, 1992, Myer, 2001).

Hypothesis 6 . Turkey is more likely to attract FDI forming JV with local partners whereas Poland is more likely to attract FDI forming WOS.

\section{Empirical Test}

We acquired a data set from the World Bank's Private Participation in Infrastructure (PPI) Database. The private participation projects in Turkey and Poland reached closure during the period 1990-2009 (inclusive). Closure occurs when private entities agree to a legally binding agreement to invest funds or provide services. After excluding projects with missing data, a total of 105 projects from Turkey and 192 projects from Poland are included in our sample. Out of the 105 projects in Turkey, 61 projects have FDI. Out of the 193 projects in Poland, 159 projects have FDI.

\subsection{Variables}

FDI. Foreign direct investments are coded 1 when foreign investors participate in the project.

Market Size. Market size is measured by GDP, obtained from World Development Indicators (WDI). The GDP is measured in billions of dollars in the host country-Turkey or Poland-in the year when the private participation project reached closure.

Political stability. Henisz's Political constraint index is used to measure political stability in an institutional environment. This index measures the feasibility of change in policy given the structure of a nation's political institutions. The index is scaled 0 to 1 with 0 indicating most hazardous political environment and 1 indicating extensive checks and balances in the institution. Each country and year is matched with the private participation project data. The political stability data for year 2007 are used for the private participation projects in 2008 and 2009 since the index ends in 2007.

Greenfield. When MNEs participate in private projects, they can build and operate a new facility. This greenfield entry mode in private participation is called founder privatization (Wojnicka, 2001). Another typical entry mode is acquisition-MNEs acquire assets of the state owned enterprise through an asset sale, public offering, or mass privatization program. FDI with greenfield entry mode is coded 1 and FDI with acquisition entry mode is coded 0 .

FDI with WOS. FDI that forms wholly owned subsidiaries is coded 1 and FDI that forms JV with local partners is coded 0.

Control variables. Market-supporting institutions may become stronger over time because of cumulative reforms undertaken with individual privatization transactions (Ramamurti, 2000). Given the institutional development over time, it is possible that new technologies arise over time that lower the transaction costs present in markets (David \& Han, 2004). We control for the age of the projects measured by the year lapsed from when the projects were set up till 2009. Total investment, the sum of investment in physical assets and payments to the government is controlled. Total investment is recorded in millions of US dollars. Primary industry sectors, namely, energy, telecommunication, and transportation and water sewage sectors are controlled.

Binomial logistic regression is used to test hypotheses $1,2,3$, and 6 . The maximum likelihood estimates of the parameters are obtained employing the regression model. To test hypotheses 4 and 5 , we perform post-estimation tests to compare regression coefficients across different samples.

\subsection{Findings}

Table 1 summarizes the variables and Table 2 reports the results of the logistic regression model. Model 1 tests Hypotheses 1, 2, and 3. The coefficients are interpreted as affecting the odds of attracting FDI. We find that the 
coefficient of GDP is significant and negative, indicating that a larger market is less likely to attract FDI. Thus, Hypothesis 1 is not supported. The coefficient of political stability is significant and positive, indicating that a more politically stable market is more likely to attract FDI, supporting Hypothesis 2. The variable Turkey is significant and negatively related to FDI, showing that Turkey is less likely to attract FDI than Poland, supporting Hypothesis 3.

Table 1: Descriptive statistics

\begin{tabular}{|l|c|c|c|c|c|c|c|c|c|c|c|c|}
\hline & Mean & S.D. & 1 & 2 & 3 & 4 & 5 & 6 & 7 & 8 & 9 & 10 \\
\hline 1 FDI & 0.74 & 0.44 & & & & & & & & & & \\
\hline 2 Market size & 262.56 & 178.52 & -0.30 & & & & & & & & & \\
\hline 3 Political stability & 0.39 & 0.10 & 0.10 & -0.04 & & & & & & & & \\
\hline 4 Greenfield & 0.71 & 0.45 & -0.19 & -0.10 & 0.31 & & & & & & & \\
\hline 5 FDI with JV & 0.17 & 0.37 & 0.27 & 0.00 & 0.03 & 0.04 & & & & & & \\
\hline 6 FDI with WOS & 0.57 & 0.50 & 0.68 & -0.27 & 0.07 & -0.20 & -0.52 & & & & & \\
\hline 7 Turkey & 0.35 & 0.48 & -0.30 & 0.46 & -0.01 & 0.08 & 0.27 & -0.44 & & & & \\
\hline 8 Total investment & 319.95 & 673.71 & 0.11 & 0.11 & 0.02 & -0.15 & 0.16 & -0.02 & 0.22 & & & \\
\hline 9 Age & 5.62 & 4.61 & 0.11 & -0.56 & -0.07 & 0.05 & 0.01 & 0.09 & -0.11 & -0.04 & & \\
\hline 10 Energy & 0.34 & 0.47 & -0.05 & 0.53 & -0.03 & -0.20 & -0.13 & 0.05 & 0.17 & -0.09 & -0.23 & \\
\hline 11 Telecommunication & 0.53 & 0.05 & 0.05 & -0.56 & 0.12 & 0.41 & 0.07 & -0.00 & -0.19 & 0.08 & 0.17 & -0.75 \\
\hline
\end{tabular}

Table 2: Binomial logistic regression of foreign direct investment

\begin{tabular}{|c|c|c|c|}
\hline & $\begin{array}{l}\text { Model } 1 \\
\text { FDI }\end{array}$ & $\begin{array}{c}\text { Model } 2 \\
\text { FDI before } 2004\end{array}$ & $\begin{array}{c}\text { Model } 3 \\
\text { FDI after } 2004\end{array}$ \\
\hline Market size & $-0.01^{* * *}$ & $-0.03^{\star *}$ & -0.01 ** \\
\hline Political stability & $4.17^{*}$ & -0.12 & $7.83^{\star}$ \\
\hline Turkey & $-0.93^{* *}$ & 0.73 & $-1.89^{* \star *}$ \\
\hline Greenfield & $-1.70^{\star * *}$ & -0.85 & $-2.78^{\star \star \star}$ \\
\hline Total investment & $0.001^{\star *}$ & 0.00 & $0.002^{* *}$ \\
\hline Age & -0.03 & $-0.18 \dagger$ & -0.06 \\
\hline Energy & $1.38^{\star}$ & $1.56 \dagger$ & $1.74 \dagger$ \\
\hline Telecommunication & -0.004 & -0.14 & -0.36 \\
\hline Constant & $2.23^{*}$ & $7.94^{\star \star \star}$ & 2.34 \\
\hline $\mathrm{N}$ & 297 & 135 & 162 \\
\hline Pseudo R2 & 0.21 & 0.14 & 0.37 \\
\hline Chi2 & $72.5^{\star \star \star}$ & $18.85^{\star}$ & 73.91 ** \\
\hline $1^{*} p<0.05^{* \star} p<0.01{ }^{* * \star} p<0.001$ & & & \\
\hline
\end{tabular}

To test Hypothesis 4, we perform post-estimation tests to compare regression coefficients in two samples-investments made before and after Poland's EU accession. The results of the logistic regression models in these two samples are presented in Model 2 and Model 3 in Table 2. Poland officially entered the EU in 2004. Model 2 includes the sample before year 2004 and Model 3 includes the sample after (and including) year 2004. The variable Turkey is significant and negative in Model 3 and insignificant in Model 2, suggesting that Turkey is less likely to attract FDI than Poland only after Poland's EU accession. To test if the coefficients of the variable Turkey are significantly different in the two samples, the estimation results of Model 2 and Model 3 are stored and combined. We use STATA's post-estimation command "test" to compare the two coefficients. We find that the coefficients of the variable Turkey are significantly different in Model 2 and Model 3, supporting Hypothesis 4.

To test Hypothesis 5, we also perform post-estimation tests to compare regression coefficients in two samplesinvestments made in Turkey and in Poland. The results of the logistic regression models in these two samples are presented in Model 4 and Model 5 in Table 3. Model 4 includes 105 investments in Turkey and Model 5 includes 192 investments in Poland. To test if acquisition projects are more likely to attract FDI in Turkey than in Poland, we compare the coefficients of the variable greenfield across the two samples. The estimation results of Model 4 and Model 5 are stored and combined. We use STATA's post-estimation command "test" to compare the two coefficients. We find that the coefficients of the variable greenfield are significantly different in Model 4 and Model 5, indicating that the relationship between greenfield entry mode and FDI is different in Turkey than in Poland. Since the coefficient of greenfield is 
negative in Model 4 and positive in Model 5, we conclude that acquisition projects are more likely to attract FDI in Turkey than in Poland, and greenfield projects are more likely to attract FDI in Poland than in Turkey. Hypothesis 5 is supported.

Table 3: Binomial logistic regression of foreign direct investment

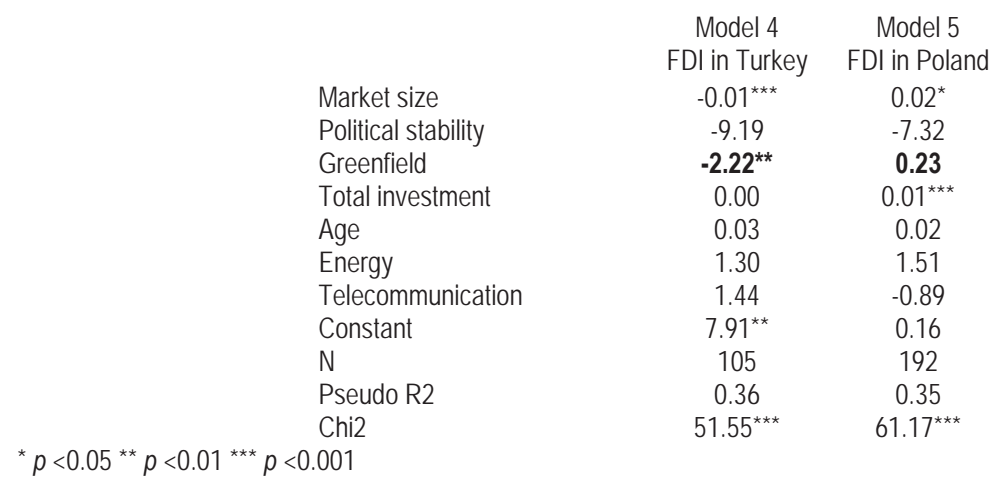

Hypothesis 6 compares the ownership structure of FDI in Turkey and Poland. A subsample including 220 FDI projects in Poland and Turkey is used in the logistic regression model. Model 6 in Table 4 presents the result. The dependent variable is FDI with WOS. The coefficient of Turkey is significant and negative, indicating that Turkey is negatively related to FDI with WOS. The result shows that Turkey is more likely to attract FDI with JV and Poland is more likely to attract FDI with WOS, supporting Hypothesis 6.

Table 4: Binomial logistic regression of foreign direct investment with wholly owned subsidiaries

$\begin{array}{lc} & \text { Model } 6 \\ & \text { FDI with WOS } \\ \text { Market size } & -0.002 \\ \text { Political stability } & 2.80 \\ \text { Turkey } & -2.35^{* * *} \\ \text { Greenfield } & -1.60^{\star} \\ \text { Total investment } & 0.43 \\ \text { Energy } & 1.96^{\star *} \\ \text { Telecommunication } & 1.11 \dagger \\ \text { Constant } & 108.76 \\ \text { N } & 220 \\ \text { Pseudo R2 } & 0.23 \\ \text { Chi2 } & 54.64^{* * *} \\ { }^{\dagger} p<0.1 * p<0.05 * * p<0.01 * * * 0<0.001 & \end{array}$

\section{Discussion}

In this study, we find that entry mode and ownership structure are related to FDl's location choice. In the two emerging markets under study, the institutional environments tend to be uncertain, especially in Turkey. We integrate TCE and institution-based view to test the relationship between FDl's location choice and organizational forms.

This study contributes to the literature by exploring the strategic choices and attributes of institutional environments. There are three major findings in our study. First, our results show that a politically stable environment attracts FDI, but the sheer size of a market does not attract FDI. It is possible that in our sample, Poland's relative attraction to FDI compensates for its smaller market size. Poland's advantage over Turkey of attracting FDI increases following its EU accession. Second, different entry modes are favored in different locations. Same as Demirsar's (2006) finding, our results show that FDI in Turkey are more likely to participate in acquisitions of existing Turkish companies. FDI in Poland, however, are more likely to take greenfield entry mode and establish new facilities. Third, regarding 
ownership structure, Turkey is more likely to attract FDI forming joint ventures with local partners whereas Poland is more likely to attract FDI that sets up wholly owned subsidiaries.

Uncertainty in institutions has important implications for the design and implementation of privatization programs and also for the strategic responses of private entities that participate in these projects (Ramamurti, 2000). Our findings may have ramifications for FDI to choose entry mode and ownership structure in private participation projects based on the institutional environments. North (1990) argues that institutional rules develop upon path-dependent projectories. One source of path dependency in institutional change in privatization is that the conformity to public sector template is likely to continue in the newly privatized projects. This creates the necessity for foreign investors to choose the location and entry strategy that facilitates transactions in an uncertain institutional environment.

\section{Conclusion}

After decades of reform, the market institutions in emerging economies are still inadequate, albeit improving. The turbulent environment and underdeveloped institutions add general uncertainty to foreign direct investments. Our study taps into an important and current phenomenon of foreign investors' private participation in two important emerging economies.

Two contributions emerge in this study. We draw on the location factor in Dunning's eclectic paradigm and integrate TCE and institution-based view to explore the relation between foreign market entry mode, ownership structure, and location. Dunning (2009) argues that research on FDI without recognizing the relationship between MNE's location choice and organizational forms fails to understand the attractiveness of locations. We identify and test country-specific and organization-specific characteristics that affect transactions in the host country. Second, We validate the significance of accession to the EU as a determinant of FDI. EU accession entails alignment by countries with EU policies such as competition and intellectual property law, and significantly attracts FDI. Our findings provide directions to FDI in emerging markets regarding of organizational forms, and also offer guidance to countries that race to attract FDI.

There are some limitations to our study. The assumption that FDI has the option to choose certain entry modes, as shown in most entry mode literature, may not be true (Andersen, 1997). Governments may restrict private participation in certain projects, affecting the choice of FDI entry mode. The World Bank recognizes that private participation in foreign investments could be complicated. Future research on arrangements of privatization projects needs to be conducted at a level of detail that enables us to recognize government restrictions and distinguish the actual coordination mechanisms used to manage transactions. We hope that future research will challenge and extend what we have found.

Overall, this study contributes to the research field of FDI by theoretically exploring and empirically testing the interrelationship between the choice of location, entry mode, and ownership structure. Our findings provide a timely guide to FDl's participation in the privatization process in emerging economies. FDI also affects institutional changes in host countries. As Turkey prepares for EU membership, a continuous effort to attract FDI will help Turkey to prove its significant development of the institutional environment.

\section{References}

Agarwal, S. \& Ramaswami, S. 1992. Choice of foreign market entry mode: impact of ownership, location and internalization factors. Journal of International Business Studies, 23(1): 1-27.

Ahmed, Z. U., Mohamad, O., Tan, B., \& Johnson, J. P. 2002. International risk perceptions and mode of enry: A case study of Malaysian multinational firms. Journal of Business Research, 55: 805-13.

Andersen, O. 1997. Internationalization and market entry mode: A review of theories and conceptual frameworks. Management International Review, 37: 27-42.

Anderson, E. \& Gatingnon, H. 1986. Modes of foreign entry: a transactions cost analysis and propositions. Journal of International Business Studies, 17: 1-26.

Argyres, N. S. \& Liebeskind, J. P. 1999. Contractual commitments, bargaining power, and governance inseparability: Incorporating history into transaction cost theory. Academy of Management Review, 24: 49-63.

Baldwin, R., Francoise, J., \& Portes, R. 1997. The costs and benefits of Eastern Enlargement: The impact on the EU and Central Europe. Economic Policy 24: 125-70.

Bandelj, N. 2009. The global economy as instituted process: The case of Central and Eastern Europe. American sociological Review, 74: $128-49$.

Bell, J. H. J. 1996. Single or joint venturing? A comprehensive approach to foreign entry mode choice. Aldershot, England: Avebury.

Bevan, A. \& Estrin, S. 2004. The Determinants of foreign direct investment into European transition economies. Journal of Comparative Economics, 32: 775-87. 
Bieszki, M. \& Rath, H. 1989. Polish-German joint ventures. Management International Review, 29(4): 45-67.

Bockman, J. \& Eyal, G. 2002. Eastern Europe as a laboratory for economic knowledge: The transnational roots of neoliberalism. American Journal of Sociology 108(2): 10-52.

Boycko, M., Shleifer, A., \& Vishny, R. 1994. Voucher privatization. Journal of Financial Economics, 35: 249-66.

Brouthers, K. D., Brouthers, L. E., \& Werner, S. 2002. Industrial sector, perceived environmental uncertainty and entry mode strategy. Journal of Business Research, 55: 2002.

Buckley, P. J. \& Casson, M. C. 1976. The Future of the multinational enterprise. London: Macmillan.

Buckley, P. J. \& Casson, M. C. 1998. Models of the multinational enterprise. Journal of International Business Studies, 29(1): 21-44.

Buckley, P. J. \& Mathew, A. M. 1980. Dimensions of market entry behavior of recent U.K. first time direct investors in Australia. Management International Review, 20(2): 35-51.

Caves, R. E. \& Mehra, S. K. 1986. Entry of foreign multinationals into U.S. manufacturing industries. In M. Porter (Ed.) Competition in Global Industries. Boston, Massachusetts: Harvard Business School Press.

Chidlow, A., Salciuviene, L., \& Young, S. 2009. Regional determinants of inward FDI distribution in Poland. International Business Review, 18: 119-33.

Choi, C. J., Lee, S. H., \& Kim, J. B. 1999. A note on countertrade: Contractual uncertainty and transaction governance in emerging economies. Journal of International Business Studies, 30: 189-201.

Clifton, J., Comín, F., \& Fuentes, D. D. 2003. Privatisation in the European Union. Public enterprises and integration. Dordrecht: Kluwer Academic Publishers.

Conner, K. \& Prahalad, C. K. 1996. A resource-based theory of the firm: Knowledge versus opportunism. Organization Science, 7: 477 92.

Coskun, R. 2001. Determinants of direct foreign investment in Turkey. European Business Review, 13(4): 221-27.

David, R. \& Han, S.-K. 2004. A systematic assessment of the empirical support for transaction cost economics. Strategic Management Journal, 25: 39-58.

De Castro, J. O. \& Uhlenbruck, K. 1997. Characteristics of privatization: Evidence from developed, less-developed and former communist countries. Journal of International Business Studies, 28: 123-43.

Demirbag, M., Tatoglu, E., \& Glaister, K. W. 2008. Factors affecting perceptions of the choice between acquisition and greenfield entry: The case of Western FDI in an emerging market. Management International Review, 48(1): 5-38.

Demirsar, M. 2006. Western Europe: Turkey - major league FDI recipient - privatisation is sucking in unprecedented levels of foreign direct investment to Turkey. The Banker: 1-1.

Dikova, D. \& van Witteloostuijin, A. 2004. Foreign direct investment mode choice: entry and establishment modes in transition economies. Journal of International Business Studies, 38: 1013-33.

Dikova, D. \& Van Witteloostuijn, A. 2007. Foreign direct investment mode choice: entry and establishment modes in transition economies. Journal of International Business Studies, 38(6): 1013-33.

Dunning, J. H. 1997. The European internal market programme and inbound foreign direct investment. Journal of Common Market Studies, 35(2): 189-223.

Dunning, J. H. 1993. The Globalization of business. London: Routeledge.

Dunning, J. H. 2009. Location and the multinational enterprise: John Dunning's thoughts on receiving the Journal of International Business Studies 2008 decade award. Journal of International Business Studies, 40(1): 20-34.

Dunning, J. H. 1980. Toward an electic theory of international production: Some empirical tests. Journal of International Business Studies, 11(1): 9-32.

Ekeledo, I. \& Sivakumar, K. 2004. International market entry mode strategies of manufacturing firms and service firms: A resource-based perspective. International Marketing Review, 21(1): 68-101.

Erdal, F. \& Tatoglu, E. 2002. Locational determinants of FDI in an emerging market economy: Evidence from Turkey. Multinational Business Review, 10(1): 21-28.

Estrin, S., Hughes, K., \& Todds, S. 1997. Foreign direct investment in Central and Eastern Europe. London: Cassell.

Filatotchev, I., Strange, R., Piesse, J., \& Yung-Chih, L. 2007. FDI by firms from newly industrialised economies in emerging markets: corporate governance, entry mode and location. Journal of International Business Studies, 38(4): 556-72.

Gomes-Casseres, B. 1989. Ownership structures of foreign subsidiaries. Journal of Economic Behavior and Organization, 11(1): 1-25.

Harzing, A. W. 2002. Acquisitions versus greenfield investments: International strategy and management of entry modes. Strategic Management Journal, 23: 211.

Henisz, W. J. 2000. The institutional environment for economic growth. Economics \& Politics, 12(1): 1-31.

Henisz, W. J. \& Zelner, B. A. 2001. The insititution environement for telecommunications investment. Journal of Economics \& Management Strategy, 10(1): 123-47.

Hennart, J. F. 1982. Theory of multinational enterpreise. Ann Arbor: University of Michigan Press.

Hennart, J. F. 1988. A transaction cost theory of equity joint-ventures. Strategic Management Journal, 9: 361-74.

Hennart, J. F. \& Park, Y. R. 1993. Greenfield vs acquisition. Management Science, 39: 1054-70.

Hoskisson, R. E., Eden, L., Lau, C. M., \& Wright, M. 2000. Strategizing in emerging economies. Academy of Management Journal, 43: $249-67$.

Keller, A. Z., Dogan, C., \& Eroglu, O. 1994. Evaluating privatization policies in Turkey. The International Journal of Public Sector Management, 7(1): 15-24. 
Kim, W. C. \& Huang, P. 1992. Global strategy and multinationals' entry mode choice. Journal of International Business Studies, 23: 2954.

Kogut, B. \& Zander, U. 2003. Knowledge of the firm and the evolutionary theory of the multinational corporation. Journal of International Business Studies, 34: 516-29.

Larimo, J. 2003. Forms of investment by Nordic firms in world markets. Journal of Business Research, 56: 791-803.

Martinez, R. J. \& Dacin, M. T. 1999. Efficiency motives and normative logic: Combining transaction costs and institutional logic Journal of Management, 25(75-95)

Megginson, W. L. \& Netter, J. M. 2001. From state to market: A survey of empirical studies on privatization. Journal of Economic Literature, 39(2): 321-89.

Meyer, K. E. 2001. Institutions, transaction costs, and entry mode choice in Eastern Europe. Journal of International Business Studies, 32: $357-67$.

Meyer, K. E. \& Estrin, S. 2001. Brownfield entry in emerging markets. Journal of International Business Studies, 32(3): 575-84.

Meyer, K. E., Estrin, S., Bhaumik, S., \& Peng, M. W. 2009. Institutions, resources, and entry strategies in emerging economies. Strategic Management Journal, 30(1): 61-80.

Meyer, K. E. \& Peng, M. W. 2005. Probing theoretically into Central and Eastern Europe: Transactions, resources, and institutions. Journal of International Business Studies, 36: 600-21.

Myer, K. E. 2001. Institutions, transaction costs, and entry mode choice in Eastern Europe. Journal of International Business Studies, 32(2): 357-67.

North, D. C. 1990. Institutions, institutional change, and economic preference. New York: Norton.

Peng, M. W. \& Jiang, Y. 2005. Entrepreneurial strategies during institutional transitions. In L. A. Keister (Ed.) Research in the Sociology of Work: JAl/Elsevier Press.

Peng, M. W., Wang, D., \& Jiang, Y. 2008. An institution-based view of international business strategy: A focus on emerging economies. Journal of International Business Studies, 39: 920-36.

Porter, M. 1990. The competitive advantage of nations. London: Macmillan.

Ramamurti, R. 2000. A multilevel model of privatization in emerging economies. Academy of Management Review, 25: 525-50.

Shenkar, O. \& Von Glinow, M. A. 1994. Paradoxes of organizational theory and research: Using the case of China to illustrate national contingency. Management Science, 40: 56-71.

Teece, D. 1986. Firm boundaries, technological innovation, and strategic management. In L.G. Thomas (Ed.) The economics of strategic planning. Lexington, MA: Lexington Books.

Uhlenbruck, K. \& De Castro, J. O. 2000. Foreign acquisitions in Central and Eastern Europe: Outcomes of privatization in transitional economies Academy of Management Journal, 43(3): 381-402.

World Investment Report. 2010. World Investment Report. Geneva: UNCAD.

World Investment Report 1994. World Investment Report Geneva: UNCAD.

Vickers, J. \& Wright, V. 1989. The politics of industrial privatization in Western Europe: An overview. In J Vickers \& V Wright (Eds.) The politics of privatiztion in Western Europe. London: Frank Cass.

Wan, W. \& Hoskisson, R. E. 2003. Home country environments, corporate diversification strategies, and firm performance. Academy of Management Journal, 46: 27-45.

Welfens, P. J. J. 1992. Foreign investment in the East European transition. Management International Review, 32(3): 199-99.

Williamson, O. E. 1985. The economic institutions of capitalism: Free Press: New York.

Wojnicka, E. 2001. Foreign direct investment in the privatisation of the Polish economy. Intereconomics, 36(6): 305-14.

Wright, M., Filatotchev, I., Hoskisson, R. E., \& Peng, M. W. 2005. Strategy research in emerging economies: Challenging the conventional wisdom. Journal of Management Studies, 42(1): 1-33. 